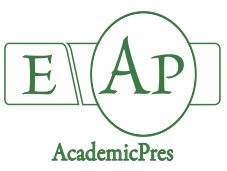

Sun R-T et al. (2021)

Notulae Botanicae Horti Agrobotanici Cluj-Napoca

Volume 49, Issue 3, Article number 12454

DOI: $10.15835 /$ nbha 49312454

Review Article

\title{
A review of the interaction of medicinal plants and arbuscular mycorrhizal fungi in the rhizosphere
}

\section{Rui-Ting SUN ${ }^{1}$, Ze-Zhi ZHANG ${ }^{2}$, Nong ZHOU ${ }^{3}$, A.K. SRIVASTAVA Kamil KUČA ${ }^{5}$, Elsayed F. ABD-ALLAH ${ }^{6}$, Abeer $\mathrm{HASHEM}^{7}$, Qiang-Sheng WU ${ }^{1,5 *}$}

\author{
${ }^{1}$ Yangtze University, College of Horticulture and Gardening, Jingzhou, Hubei 434025, China; $1425895578 @ q q . c o m$; \\ wuqiangsh@163.com (*corresponding author) \\ ${ }^{2}$ Shiyan Academy of Agricultural Sciences, Shiyan, Hubei 442000, China; 179117170@qq.com \\ ${ }^{3}$ Chongqing Three Gorges University, College of Biology and Food Engineering, Chongqing 404120, China; erhaizn@126.com \\ ${ }^{4}$ ICAR-Central Citrus Research Institute, Nagpur, Maharashtra, India; aksrivas2007@gmail.com \\ ${ }^{5}$ University of Hradec Kralove, Faculty of Science, Department of Chemistry, Hradec Kralove, Czech Republic; kamil.kuca@uhk.cz \\ ${ }^{6}$ King Saud University, Faculty of Food and Agricultural Sciences, Plant Production Department, Riyadh 11451, \\ Saudi Arabia; eabdallah@ksu.edu.sa \\ ${ }^{7}$ King Saud University, Botany and Microbiology Department, College of Science, P.O. Box. 2460, Riyadh 11451, \\ SaudiArabia; habeer@ksu.edu.sa
}

\begin{abstract}
Medicinal plants are well known to have the advantages of high concentration of medicinal ingredients having clinical importance, curative value, small toxic and side effects. Important compounds viz., paclitaxel, camptothecin, and vincristine have been developed from medicinal plants as first-line of clinical drugs, leading to their consistently increasing demand globally. However, the destruction of natural environment due to excessive mining threatened such resources jeopardizing the successful growing of medicinal plants. A group of beneficial arbuscular mycorrhizal (AM) fungi is known to exist in the rhizosphere of medicinal plants, which can establish a reciprocal symbiosis with their roots, namely arbuscular mycorrhizas. These AM fungi are pivotal in the habitat adaptation of medicinal plants. Studies have demonstrated that AM fungi aided in growth promotion and nutrient absorption of medicinal plants, thereby, accelerating the accumulation of medicinal ingredients and aiding resistance against abiotic stresses such as drought, low temperature, and salinity. An AMlike fungus Piriformospora indica is known to be cultured in vitro without roots, later showed analogous effects of AM fungi on medicinal plants. These fungi provide new mechanistic pathways towards the artificial cultivation of medicinal plants loaded with ingredients in huge demand in international market. This review provides an overview of the diversity of AM fungi inhabiting the rhizosphere of medicinal plants, and analyzes the functioning of AM fungi and $P$. indica, coupled with future lines of research.
\end{abstract}

Keywords: endophytic fungi; medicinal components; medicinal plants; mycorrhiza; Piriformospora indica; symbiosis

Received: 28 Jul 2021. Received in revised form: 21 Aug 2021. Accepted: 09 Sep 2021. Published online: 23 Sep 2021.

From Volume 49, Issue 1, 2021, Notulae Botanicae Horti Agrobotanici Cluj-Napoca journal uses article numbers in place of the traditional method of continuous pagination through the volume. The journal will continue to appear quarterly, as before, with four annual numbers. 


\section{Introduction}

Medicinal plants refer to all or part of plants that can be directly used as medicine or extraction of a drug (Zhao et al., 2019). In particular, authentic medicinal herbs originating from specific production areas have received widespread attention due to their high content of medicinal compounds, clinical significance, unique therapeutic impact, and minimal toxic side effects (Zhan et al., 2020). As a result, their demand is rising dayby-day. For example, paclitaxel, camptothecin, and vincristine have been developed as first-line clinical drugs (Yang, 2018). The differentiating reasons between native and non-native medicinal plants include germplasm resources, growth environment and climatic conditions (Zhan et al., 2020). China is the leading country with the largest number of medicinal plants and blessed with longest history of growing medicinal plants in the world. However, due to destruction of natural environment, and long-term over-exploitation, the resources of many medicinal plants are facing an inevitable loss of resources (Zhao et al., 2019; Ullah et al., 2020). With rapid development of the global herbal market, Indian herbal medicine, Western herbal medicine, and Chinese herbal medicineare on the verge of extinction due to deterioration in natural habitat of medicinal plants (Ullah et al., 2020). It is important to improve the survival rate of medicinal plants and protect their native soil environment.

Arbuscular mycorrhizal (AM) fungi in the soil form symbioses with most of the terrestrial plants, viz., arbuscular mycorrhizas (Khan et al., 2020; Meng et al., 2020). The extraradical hyphae of arbuscular mycorrhizas outside the root surface can extend into the areas, otherwise inaccessible to the roots to absorb water and nutrients and delivery them into the host to accelerate the acquisition of such important inputs by the host and enhancing the stress tolerance (Khan et al., 2020; Wu et al., 2020; Cheng et al., 2021; Zou et al., 2021a, 2021b). Most of medicinal plants including Angelica dahurica, Atractylodes lancea, barberry, ginseng, peony, Pinellia pinellia, Polygonum cuspidatum, Panax notoginseng, Tulipa gesneriana and Yucca filamentosa form arbuscular mycorrhizas, which thus, affect the plant growth performance, active ingredient accumulation, and stress tolerance (Figure 1) (Ma et al., 2005; Gao et al., 2007; Ren et al., 2007; Cai et al., 2009; Cheng et al., 2009; Tebuqin et al., 2015). Studies indicated that AM fungi affected secondary metabolic processes of plants, including flavonoids and terpenoids (Pongrac et al., 2008; Smith et al., 2010; Yadav et al., 2013; Zeng et al., 2014). Most of terpenoids and alkaloids are the primary active ingredients of medicinal plants and display antiinflammatory, antibacterial, cardiotonic and anticancer effects (Zhang et al., 2015). AM fungal species Glomus mosseae promoted the synthesis and accumulation of flavonoids with host plant as Astragalus membrananceus, and also promoted the accumulation of berberine, fibrin, and jatrorrhizine in Phellodendron amurense (Fan et al., 2006). AM fungi up-regulated the expression of key biosynthesis genes in Artemisia annua and Stevia rebaudiana to promote the accumulation of artemisinin and stevioside (Mandal et al., 2015a, 2015b). However, artificially cultivated medicinal plants often reported to have a lesser abundance of AM fungi in the rhizosphere and account for a significant decrease in plant survival. Thus, high mycorrhizal dependence of medicinal plants determines the great potential of diversified roles of AM fungi in the cultivation of medicinal plants (Labidi et al., 2015). The present review briefly summarizes the diversity of AM fungi in the rhizosphere of medicinal plants, analyzes the effects of AM fungi and AM-like fungus (Piriformospora indica) on growth, nutrient uptake, stress tolerance, and medicinal components, in addition to some thoughts on the mycorrhizal interactions.

An abundant resources of AM fungi are largely reported in the rhizosphere of medicinal plants, with a wide range of hosts (Table 1). AM fungal community and their diversity are of huge significance to understand the soil microbial environment and related underground ecosystems. The mycelial network formed by AM fungi aid in promoting the nutrient exchange and signal transfer between plants (Osborne et al., 2017).

Here, we used the Web of Science, CNKI and other databases to search the relevant papers by keywords such as mycorrhiza/mycorrhizal, medicinal plants, Piriformospora indica, endophytic fungi, medicinal components, stress, etc. Subsequently, these literatures were further screened to remove the literatures not related to AM fungi and medicinal plants. Finally, 114 papers were chosen for subsequent analysis. 


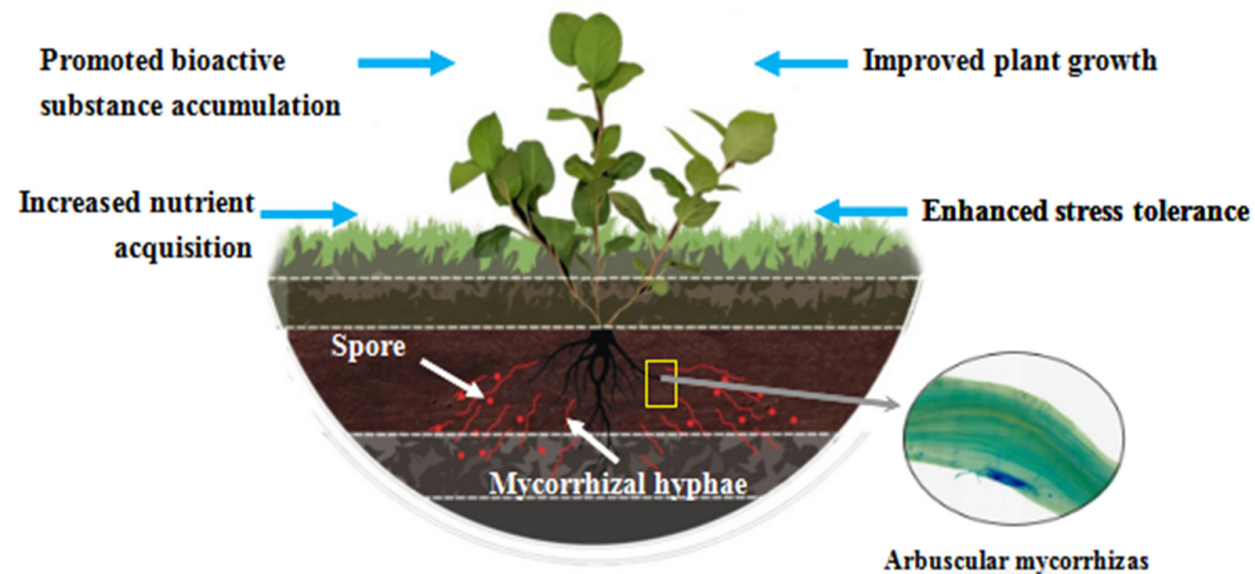

Figure 1. A diagram regarding the roles of AM fungi on medicinal plants

A large number of AM fungal spores inhabit the rhizosphere of medicinal plants. These spores germinate under suitable environmental conditions and then colonize roots by signal substances released by the host, forming arbuscules in the root cortex cells as well as a large number of intraradical mycelium. Such AM symbionts strongly contribute to improved plant growth, increased nutrient acquisition, promoted medicinal components accumulation, enhanced stress resistance, etc.

Table 1. Diversity of AM fungi in medicinal plants

\begin{tabular}{|c|c|c|}
\hline Host plants & AM fungi species & References \\
\hline Aconitum carmichaeli & Glomus caledonium, G. geospora, G. occulum, G. pallidum, and Gigaspora gigantean & Li et al., 2011 \\
\hline Aloe vera & $\begin{array}{l}\text { Acaulospora leavis, G. clavisporum, G. etunicatum, G. caledonium, G. luteum, and } \\
\text { Scutellospora gregaria }\end{array}$ & Koul et al., 2012 \\
\hline Artemisia nilagrica & G. diaphanum, G. etunicatum, G. intraradices, G. spurcum, and Sc. gregaria & Koul et al., 2012 \\
\hline Atractylodes macrocephala & G. constrictum, G. geospora, G. mossea, and G. pallidum & Li et al., 2011 \\
\hline Coleus aromaticus & $\begin{array}{c}\text { Acaulospora appendiculota, Ac. leavis, G. aggregatum, G. costricum, G. fascieulatum, G. } \\
\text { mosseae, G. macrocarpum, Entrophosphora spp., and Scutellospora spp }\end{array}$ & $\begin{array}{l}\text { Mahobiya et al., } \\
2018\end{array}$ \\
\hline Coptis chinensis & $\begin{array}{l}\text { G. caledonium, G. geospora, G. mosseae, G. diaphanum, G. occulum, and } \\
\text { Acaulosporamella }\end{array}$ & Li et al., 2011 \\
\hline Curcuma decipiens & $\begin{array}{c}\text { Ambispora leptoticha, G. caledonium, G. constrictum, G. fascieulatum, G. geosporum, } \\
\text { and G. multicaule }\end{array}$ & $\begin{array}{l}\text { Radhika et al., } \\
2010\end{array}$ \\
\hline Hemidesmus indicus & Am. leptoticha, G. fasciculatum, G. geosporum, G. maculosum, and G. multicaule & $\begin{array}{l}\text { Radhika et al., } \\
2010\end{array}$ \\
\hline Lonicera japonica & G. constrictum, G. geosporum, G. mosseae, and G. versiforme & Gai et al., 2000 \\
\hline $\begin{array}{l}\text { Paris polyphylla } \\
\text { var. yunnanensis }\end{array}$ & $\begin{array}{c}\text { Acaulospora appendicola, Ac. brieticulata, Ac. excavata, Ac. foveata, Ac. lacunosa, Ac. } \\
\text { leavis, Ac. koskei, Ac. myriocarpa, Ac.polonica, Ac. rehmii, Ac. scrobiculata, G. albidum, G. } \\
\text { ambisporum, G. deserticola, G. luteum, G. fragarioides, G.microaggregatum, G. } \\
\text { multiforum, G. luteum, G. fragarioides, G. microaggregatum, G. multiforum, Gigaspora } \\
\text { albida, Gi. margarita, Gi. ramisporophora, Scutellospora calospora, Sc. Gilmorei, and Sc. } \\
\text { pellucida }\end{array}$ & Zhou et al., 2009 \\
\hline Plantago asiatica & G. intraradices & $\begin{array}{l}\text { Zhang et al., } \\
2006\end{array}$ \\
\hline Radix Scrophulariae & $\begin{array}{c}\text { G. constrictum, G. diaphanum, G. geospora, G. mosseae, G. occulum, G. reticulatum, and } \\
\text { Gigaspora gigantean }\end{array}$ & Li et al., 2011 \\
\hline Rauwolfia serpentina & $\begin{array}{l}\text { Ac. appendiculota, Ac. leavis, G. aggregatum, G. costricum, G. fasciculatum, G. mosseae, } \\
\text { G. macrocarpum, G. geosporum, Gigaspora spp., Scutellospora spp., and Sclerocystis spp. }\end{array}$ & $\begin{array}{l}\text { Mahobiya et al., } \\
2018\end{array}$ \\
\hline Scutellaria baicalensis & G. geosporum and $G$. versiforme & $\begin{array}{c}\text { Zhang et al., } \\
2006 \\
\end{array}$ \\
\hline Solanum nigrum & Gigaspora margaria & Gai et al., 2000 \\
\hline Solanum nigrum & Glomus caledonium & $\begin{array}{c}\text { Zhang et al., } \\
2006\end{array}$ \\
\hline Tagetes erecta & G. fistulosum, G. luteum, G. etunicatum, and S. coralloidea & Koul et al., 2012 \\
\hline Withania somnifera & G. clariodeum, G. etunicatum, G. fistulosum, and $G$. intraradices & Koul et al., 2012 \\
\hline
\end{tabular}




\section{Rhizosphere diversity of AM fungi}

Rich resources of AM fungi (Table 1) have been isolated and identified in medicinal plants, especially in China. Ma et al. (2005) studied the colonization status of AM fungi on 38 medicinal plants belonging to 21 families in Chongqing (China) and reported that 30 species of these medicinal plants formed the structures of AM. As many 66 species of AM fungi have been reported in rhizosphere of 20 medicinal plants in Zhangzhou (China), with Glomus as the dominant genus (Jiang, 2012a). Zhao et al. (2010) isolated 23 species of AM fungi belonging to 3 family members from 10 medicinal plants in Anguo (China)with G.geosporum and G. mosseae as dominant species. Ten and twenty-six species of AM fungi were isolated, respectively, from rhizosphere of ginseng in Jilin (China) (Xing et al., 2000) and Begonia fimbriata (Su et al., 2018), featuring predominant genus of AMs such as Acaulospora, Glomus, Scutellospora, and Gigaspora in B. fimbriata. In the region of southern region of Fujian (China), 91 species of AM fungi belonging to five genera (Acaulospora, Archaeospora, Gigaspora, Glomus, and Scutellospora) were isolated from the rhizosphere of medicinal plants, with Glomus as predominant genus (Jiang, 2012b).

In addition to China, the diversity of AM fungi within rhizosphere of medicinal plants has also been widely identified in India, Bangladesh, Poland, etc (Koul et al., 2012; Mahobiya et al., 2018; Radhika et al., 2010). Radhika et al. (2010) studied the AM fungal diversity of 36 medicinal plants in Mount Ghat (India), showing 30 of them could form AM structures, and 42 species of AM fungi belonging to 5 genera were isolated and identified. Koul et al. (2012) from India found 42 species of AM fungi from the rhizosphere of medicinal plants. Of these, 6 species of AM fungi were identified in Aloe vera, 5 species of AM fungi in Artemisia annua, and marigold. Parmita et al. (2008) observed the occurrence of AM structures in 35 medicinal plants from the Rajsha University in Bangladesh from a total of 40 medicinal plants. Zubek et al. (2009) isolated 30 species of AM fungi in rhizosphere of 31 medicinal plants in Azieron University, Poland. Such vast and rich resources of AM fungi are the solid basis for their future application in medicinal plants.

\section{Physiological roles of AM fungi}

Promotion in growth and nutrient uptake

The formation of AM symbionts (Figure 1) was observed to improve the nutrient uptake, resistance to biotic and abiotic stresses, and phytohormone balance, collectively responsible for elevated growth and development (Zhu et al., 2011; Abdel-Fattah et al., 2014; Fan et al., 2017). Jia et al. (2020) observed that AM fungi were able to colonize Salvia miltiorrhiza, which stimulated the accumulation of biomass. Huang et al. (2011) reported that AM species viz., G. mosseae and G. versiforme significantly increased the uptake of N, P, and $\mathrm{K}$ by Artemisia annua, besides increasing the chlorophyll content, transpiration rate, and shoot biomass of the plant. Our data also showed an improvement of plant growth in Reynoutria japonica at five weeks after inoculation with an AM fungus Funneliformis mosseae under sand-culture (Figure 2a) and soil-culture (Figure 2b) conditions.

\section{Enhancement in abiotic stress tolerance}

Drought tolerance

Drought is a major factor threatening the production of medicinal plants, and water deficit further impairs the physiological and biochemical functions of plants, resulting in reduced accumulation of active ingredients in medicinal plants (Liu et al., 2018). Studies demonstrated that inoculation with AM fungi upregulated the relative expression of PtFe-SOD, PtMn-SOD, PtPOD, and PtCAT1 genes in trifoliate orange plants under drought stress, indicating the distinctive role of mycorrhizal fungi in increase developing of antioxidant protected system under soil moisture stress condition (He et al., 2017; Wei et al., 2018; Zhang et al., 2019a; He et al., 2020). It has been shown that mycorrhizas altered the fatty acid composition and content of roots and its saturation to improve the plant ability to withstand against drought resistance, as a result of 
AM-induced the expression of genes regulating fatty acid dehydrogenases in roots (Wu et al., 2019). Mycorrhizal fungi increase the photosynthetic and transpiration rates (Khalvati et al., 2005; Zhang et al., 2013; Bitterlich et al., 2018; Mathur et al., 2019; Langeroodi et al., 2020), optimize root architecture and root-hair length (Zhang et al., 2019b), improve rhizosphere microenvironment (Cheng et al., 2021a), and polyamine metabolism of plants in response to drought stress (Wu et al., 2013; Hashem et al., 2019; Cheng et al., 2021b; Zou et al., 2021).
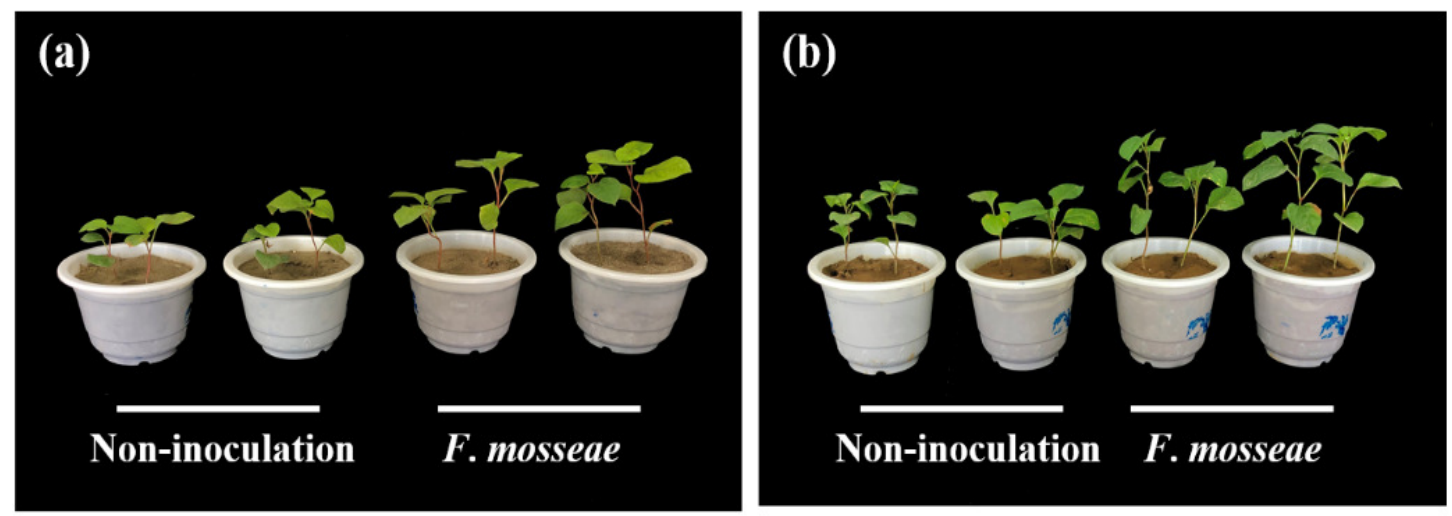

Figure 2. Plant growth responses of Polygonum cuspidatum Sieb. et Zucc under sand-culture (a) and soilculture (b) conditions after inoculation with an AM fungus Funneliformis mosseae for five weeks (unpublished data)

Liu et al. (2015) observed that the AM fungi colonization improved the plant growth and increased the nutrient uptake in Lonicera japonica, and the effect was more significant under drought stress than under ample water. Mycorrhizal fungi significantly promoted the content of $\mathrm{N}, \mathrm{P}$, and $\mathrm{K}$, in addition to water uptake in Eriobotrya japonica under drought stress (Zhang et al., 2012). The results of Zhao et al. (2007) showed that AM fungal inoculation significantly increased chlorophyll proline contents, superoxide dismutase activity, reduced malondialdehyde content and cell membrane permeability, but improved the seedling survival under drought condition, due to improved drought resistance of Forsythia suspensa. Kumar et al. (2016) reported that AM fungal inoculation resulted in higher leaf relative water content and water-use-efficiency of Abelmoschus esculentus under drought stress. Xie et al. (2017) reported that glycyrrhizic acid and glycyrrhizin content of roots increased significantly following the AM fungal inoculation in Glycyrrhiza uralensia under soil water deficit stress conditions. These studies suggested the multiple benefits of AM fungi on medicinal plants under drought stress conditions.

\section{Other abiotic stress}

The role of AM fungi in medicinal plants is also reported against other abiotic stresses, such as low temperature stress and salt stress. Xu et al. (2014) inoculated G. mosseae into Carthamus tinctorius under $\mathrm{NaCl}$ stress and observed an increase in shoot biomass and chlorophyll content, along with the enhancement in osmotic regulation and nutrient absorption through reduction in membrane lipid peroxidation and $\mathrm{Na}^{+}$ concentration. Karasawa et al. (2012) observed that AM fungi increased the $\mathrm{Zn}, \mathrm{Cu}$, and $\mathrm{P}$ contents in Plantago plantain under low temperature stress. In Trigonella foenumgraceum, inoculation with $G$. intraradices increased the plant $\mathrm{Fe}^{3+}$ and $\mathrm{Mn}^{2+}$ levels under $\mathrm{NaCl}$ stress conditions, and thus mycorrhizated plants expressed the better ionic balance in plants, resulting in enhanced stress tolerance (Evelin et al., 2011). Under salt stress, Prasad et al. (2011) also reported an increase in $\mathrm{K}^{+}$and decrease in $\mathrm{Na}^{+}$and $\mathrm{Cl}^{-}$following inoculation with $G$. intraradices. These results demonstrated the ability of AM fungi to enhance the resistance of medicinal plants against various abiotic stresses. Therefore, AM fungi are an important environmentally friendly attribute for medicinal plants under adversity. However, most of these works are related to the physiological responses of 
plants, and more work has to be carried out with regard to molecular responses to understand the relationship between AMs and medicinal plants.

\section{Increased synthesis of active ingredients}

An increasing number of studies showed that AM fungi influenced plant secondary metabolism and the accumulation of metabolic products, thus, significantly increasing the active ingredients in a variety of medicinal plants (Zeng et al., 2013; Kapoor et al., 2016; Welling et al., 2016). The effect of AM and AM-like fungal inoculation on change in medicinal components of medicinal plants (Table 2). Wei et al. (1991, 1989) inoculated G. epiqaeum and G. mosseae in three plants (Datura stramonium, Perilla frutescens, and Schizonepeta tenuifolia), which showed a substantial increase of essential oils in $S$. tenuifolia and hyoscyamine concentration in D. stramonium under soil P-deficit conditions. Other studies also showed a significant increase in tanshinone content of Salvia miltiorrhiza upon AM fungal inoculation (Yang et al., 2012) and in berberine, yaconine, and tetrandrine contents of Phellodendron amurense (Fan et al., 2006). In basil, AM fungal inoculation resulted in an increase in monosaccharide enol and phenylpropanoid content, however aromatic alcohols decreased, thus changing the essential oil composition of leaves (Prasad et al., 2011). The content of active ingredients of volatile oils was significantly increased in Atractylodes lancea seedlings following inoculation withAM species such as G. etunicatum, G. mosseae, and G. tortuosum (Liang et al., 2018). Inoculation with $G$. mosseae showed a significant increase in terpene content of Atractylodes macrocephala (Lu et al., 2011) and flavonoids in Astragalus propinquus (He et al., 2009) and Poncirus trifoliata (Chen et al., 2017), in addition to increased uptake of nutrients (P, $\mathrm{K}, \mathrm{Mg}, \mathrm{Cu}, \mathrm{Zn}$, and $\mathrm{Mn}$ ) in P. trifoliata (Chen et al., 2017). Therefore, AM fungi promoted the synthesis of terpenoids in plants, due to increase inpyrophosphates (isopentene pyrophosphate and dimethylallyl pyrophosphate) (Wang et al., 2020). Similarly, AM fungi stimulated the signaling molecules such as hydrogen peroxide, nitric oxide and salicylicacid in medicinal plants, regulating rate-limiting enzyme activities related to flavonoids, (phenylalanine ammonia lyase and cinnamic acid-4-hydroxylase), inhibit further the formation of caffeic acid (Wang et al., 2020).

Table 2. Effects of AM fungi and AM-like fungi (Piriformospora indica) on medicinal ingredients of medicinal plants

\begin{tabular}{|c|c|c|c|}
\hline Medicinal plants & AM fungi used & Effects on medicinal ingredients & References \\
\hline Aloe vera & Piriformospora indica & Aloe gel $\uparrow$ & Sharma et al., 2014 \\
\hline Angelica dahurica & Glomus claroideum and G. intraradices & Growth $\uparrow$ & Zhao et al., 2011 \\
\hline Aristolochia elegans Mart. & $P$. indica & Aristolochic acids $\uparrow$ & Bagde et al., 2014 \\
\hline Artemisia annua & Glomus mosseae & Artemisia carvifolia $\uparrow$ & Huang et al., 2011 \\
\hline A. nilagrica & $P$. indica & Artemisinin $\uparrow$ & Sharma et al., 2013 \\
\hline A. membranaceus & G. mosseae & Flavonoid $\uparrow$ & He et al., 2009 \\
\hline Atractylodes macrocephala & G. mosseae & Terpenes $\uparrow$ & Lu et al., 2011 \\
\hline Centella asiatica & P. indica & Asiaticoside $\uparrow$ & $\begin{array}{c}\text { Satheesan et al., } \\
2012\end{array}$ \\
\hline \multirow[t]{3}{*}{$\begin{array}{l}\text { Chrysanthemum } \\
\text { morifolium }\end{array}$} & G. aggregatum & Chlorogenic acid $\uparrow$; caffeoylquinic acid $\uparrow$ & Pan et al., 2013 \\
\hline & G. intratadices & $\begin{array}{l}\text { No significant effect on chlorogenic } \\
\text { acid and caffeoylquinic acid }\end{array}$ & \\
\hline & G. mosseae & Luteoloside $\downarrow$ & \\
\hline Dendrobium officinale & $P$. indica & Polysaccharide $\uparrow$ & Xu et al., 2021 \\
\hline Geranium spp. & G. intrradices & Essential oil $\uparrow$ & Prasad et al., 2012 \\
\hline Glycyrrhiza uralensia & Rhizophagus irregularis & Glycyrrhizic acid $\uparrow$ & Xie et al., 2017 \\
\hline \multirow[t]{2}{*}{ Inula ensifolia } & R. clarum & Thymol $\uparrow$ & Zubek et al., 2010 \\
\hline & $R$. intraradices & Thymol $\downarrow$ & \\
\hline Ocimum basilicum & Gigaspora rosea and Gi. margarita & $\alpha$-Terpineol and eugenol $\uparrow$ & $\begin{array}{l}\text { Copetta } \text { et al., } \\
2006\end{array}$ \\
\hline $\begin{array}{l}\text { Paris polyphylla var. } \\
\text { yunnanensis }\end{array}$ & Mixed AM fungi & Polyphyllin $\uparrow$ & Li et al., 2021 \\
\hline \multirow[t]{3}{*}{ Phellodendron amurense } & G. diaphanum and G. mosseae & Jatrorrhizine $\uparrow$ & Fan et al., 2006 \\
\hline & G. etunicatum and G. versiforme & Palmatine $\uparrow$ & \\
\hline & G. diaphanum and G. mosseae & Berberine $\uparrow$ & \\
\hline
\end{tabular}

$\uparrow$ and $\downarrow$ mean significant increase and decrease of the variable after inoculation with AM fungi, respectively. 
AM-accelerated accumulation of active components in medicinal plants is related to the increase of gene expression levels of synthetic-related enzymes of medicinal components (Xie et al., 2020). Li et al analyzed the change of polyphyllin in Paris polyphylla var. yunnanensis in the field after inoculated with mixed AM fungi and found the increased of polyphyllin I, II, and VII, along with the up-regulated expression of squalene epoxidasegene (PPSE) (Li et al., 2021). AM fungal inoculation could simultaneously up-regulate the expression of 1-deoxy-D-xylulose 5-phosphate (DXS) and 1-deoxy-D-xylulose 5-phosphate reductase $(D X R)$ genes in leaves of Artemisia annua and Stevia rebaudiana, thus promoting the accumulation of artemisinin (sesquiterpene) and stevioside (diterpene) (Mandal et al., 2015a, 2015b)., Nevertheless, 3-hydroxy-3methylglutaryl-CoA reductase ( $H M G R$ ) gene expression was not induced by AM fungi in Artemisia annua and Glycyrrhiza uralensis (Mandal et al., 2015b; Xie et al., 2018).

\section{Interaction of AM-like fungus $(P$. indica) with medicinal plants}

$P$. indica was reported by Verma et al. (1998) in the Thar Desert of northwest India. The fungus is an endophytic fungus, similar to AM fungus, but the difference is that it can be cultured through an artificial medium (Yang et al., 2021). Due to its in vitro culturable properties and AM-like functions, $P$. indica has been extensively studied in medicinal plants (Lou et al., 2007).

\section{Growth promotion}

$P$. indica can colonize coupled with increased plant growth of a wide range of plants, including medicinal plants such as Aloe vera and Centella asiatica (Deshmukh et al., 2006). The root and stem biomass, apart from as well as chlorophyll concentration of $A$. vera was significantly increased upon inoculation with $P$. indica (Sharma et al., 2014). P. indica also promoted the growth of other medicinal plant such as Adhatoda vasicanees, Coleus forskohlii, Spilanthes calva, and Withania somnifera (Varma et al., 1999; Das et al., 2012). Xu et al. (2021) inoculated Dendrobium officinale with $P$. indica through seed isolation culture and original bulb growth stages, which showed an early onset of germination and enhanced all plant growth promoting attributes including root growth properties length of $D$. officinale original bulbs. In addition, $P$. indica also increased the growth of $C$. asiatica (Satheesan et al., 2012; Bagde et al., 2014). The culture filtrate of $P$. indica has been reported to play a significant role in promoting the growth of Artemisia annua (Sharma et al., 2013). These results suggested that $P$. indica is highly responsive through a wide range of hosts, with strong stimulatory benefits in medicinal plants.

\section{Changes of secondary metabolites}

The secondary metabolites are considered the source of plant defense. The symbiosis between $P$. indica and medicinal plants is reported to stimulate the accumulation of secondary metabolites in host plants, such as ursolic acid, oleanolic acid, and stevioside (Kilam et al., 2015, 2017; Vassilev et al., 2017). P. indica inoculation significantly increased the gel and total phenol content in Aloe vera (Sharma et al., 2014) and polysaccharides in D. officinale (Xu et al., 2021). Studies in C. asiatica by Satheesan et al. (2012) showed significant elevation in asiaticoside content upon inoculation with $P$. indica. Interestingly the culture filtrate of $P$. indica increased aristolochic acid content (Zhao et al., 2011) as well as artemisinin content of $A$. annua (Sharma et al., 2013). In addition, $P$. indica affected the synthesis and accumulation of hormones in medicinal plants, including cytokinins (Schäfer et al., 2009), abscisic acid, gibberellins and brassinosterols (Shahabivand et al., 2017). These results amply suggested that inoculation with $P$. indica accelerated the synthesis of various secondary metabolites in medicinal plants (Table 2), but the underlying mechanisms involved are still a lot to be investigated.

Enhancement of resistance in response to heavy metal stress

The AM fungi, $P$. indica isolated from the rhizosphere of medicinal plants in the desert region (Varm et al., 1999), suggesting that the fungus is capable of averting various environmental stresses to plants. 
Shahabivand et al. (2017) observed that under Cd stress, $P$. indica increased leaf photosynthetic rate of sunflower, and enhanced the photosynthetic capacity of the plant, thus, affecting the important plant physiological processes such as plant development, nutrient balance, and antioxidant accumulation (Abadi et al., 2016; Swetha et al., 2017) While, under Cr stress, $P$. indica increased leaf, stem, and root dry weight of tobacco, besides accelerating the ascorbic acid and glutathione contents along with increased superoxide dismutase and catalase activities (Cheng, 2019).

In addition, $P$. indica enhanced drought tolerance of Chinese cabbage by reducing malondialdehyde contents, improving antioxidant enzyme activities, promoting the expression of drought-related genes, and regulating photosynthesis and thylakoid CAS protein (Sun et al., 2010). In addition, inoculation with $P$. indica increased antioxidant enzyme activities, reduced proline contents, and up-regulated drought-related gene expression levels (Xu et al., 2017). Water absorption and photosynthetic pigments were distinctly increased by $P$. indica in wheat exposed to salt stress (Zarea et al., 2012). These studies are focused on field crops, and the role of $P$. indica in medicinal plants under stress conditions has not been explored.

\section{Conclusions}

The worldwide demand for medicinal plants is on gradual upsurge. There is consistent interest in improving the growth of medicinal plants, promoting the accumulation of active ingredients, and enhancing the resistance of medicinal plants exposed to a variety of stress. The rhizosphere of medicinal plants inhabits a strong AM fungi-diversity that could be exploited for promoting growth, increased medicinal ingredients, and enhanced stress tolerance (Figure 1). Varied responses in medicinal plants results also indicated a strong need to provide high priority research to AM fungi in medicinal plants. There is still a need to focus on the following points regarding the interaction of AM fungi and medicinal plants:

(1) Many medicinal plants have specialized habitat requirements dictating the extent of their distribution, which determines the territorial nature of mycorrhizal fungi. Therefore, exploring the diversity of AM fungal populations with reference to medicinal plants would be highly imperative.

(2) There is a need to strengthen the screening of AM fungi strains, especially for the comparison of indigenous and exogenous AM fungi, in order to obtain the efficient AM fungal strain catering to physiological roles of medicinal plants. In addition, for many endangered medicinal plants, there is a critical need to enhance the investigation of AM fungi diversity in order to preserve these plants and promote their survival.

(3) An important function of AM fungi is to facilitate the synthesis of secondary metabolites as a source of disease tolerance. However, the underlying mechanisms of AM fungi action are still quite enigmatic to present day researchers. Whether, the mycorrhizal fungus acts through its own synthesis (acquired systemic resistance) or by stimulating the accumulation of active ingredients (induced systemic resistance) in medicinal plants need to be addressed urgently. Li et al. (2021) demonstrated that AM fungi promoted the expression of $P P S E$ in P. polyphylla var. yunnanensis, thus, accelerating the accumulation of polyphyllin, suggesting that AM fungi participate in such biochemical processes at the molecular level. Therefore, more attention should be paid to decode such physiological biochemical functions at the molecular level.

(4) Many of the studies in medicinal plants have been conducted under potted conditions, with very few field studies. As a result, more field work, especially with $P$. indica should be carried out in the future to generate field evidence to realize the magnified response of AM fungi. These efforts would put the growing of medicinal plants on a scientific footing. 


\section{Authors' Contributions}

Conceptualization: RLS and QSW; Data curation: RLS and QSW; Funding acquisition: EFAA; Project administration: QSW; Supervision: QSW; Writing - original draft: RTS, ZZZ, and NZ; Writing -review and editing: AKS, KK, EFAA, AH and QSW. All authors read and approved the final manuscript.

\section{Acknowledgements}

The authors would like to extend their sincere appreciation to the Researchers Supporting Project Number (RSP-2021/356), King Saud University, Riyadh, Saudi Arabia.

\section{Conflict of Interests}

The authors declare that there are no conflicts of interest related to this article.

\section{References}

Abadi V, Sepehri M (2016). Effect of Piriformospora indica and Azotobacter chroococcum on mitigation of zinc deficiency stress in wheat (Triticum aestivum L.). Symbiosis 69:9-19. https://doi.org/10.1007/s13199-015$0361-z$

Abdel-Fattah GM, Asrar AA, Al-Amri SM, Abdel-Salam EM (2014). Influence of arbuscular mycorrhiza and phosphorus fertilization on the gas exchange, growth and phosphatase activity of soybean (Glycine max L.) plants. Photosynthetica 52(4):581-588. https://doi.org/10.1007/s11099-014-0067-0

Bagde US, Prasad R, Varma A (2014). Impact of culture filtrate of Piriformospora indica on biomass and biosynthesis of active ingredient aristolochic acid in Aristolochia elegans Mart. International Journal of Biology 6(1):29-37. https://doi.org/10.5539/ijb.v6n1p29

Bitterlich M, Franken P, Graefe J (2018). Arbuscular mycorrhiza improves substrate hydraulic conductivity in the plant available moisture range under root growth exclusion. Frontiers in Plant Science 9:301. https://doi.org/10.3389/fpls.2018.00301

Cai BY, Ge JP, Jie WG, Jie WG, Yan XF (2009). The community composition of the arbuscular mycorrhizal fungi in the rhizosphere of Phellodendron amurense. Mycosystema 28(4):512-520

Chen ML, Yang G, Ye S, Li PY, Qiu HY, Zhou XT, Huang LQ, Chao Z (2017). Glomus mosseae inoculation improves the root system architecture, photosynthetic efficiency and flavonoids accumulation of liquorice under nutrient stress. Frontiers in Plant Science 8:931. https://doi.org/10.3389/fpls.2017.00931

Cheng F (2019). Preliminary study on mechanisms of reducing $\mathrm{Hg}$ contents in Nicotiana tabacum leaves conferred by Piriformospora indica. MSc Dissertation, Zhejiang University. https://doi.org/CNKI:CDMD:2.1018.263456

Cheng HQ, Giri B, Wu QS, Zou YN, Kuča K (2021a). Arbuscular mycorrhizal fungi mitigate drought stress in citrus by modulating root microenvironment. Archives of Agronomy and Soil Science https://doi.org/10.1080/03650340.2021.1878497

Cheng HQ, Zou YN, Wu QS, Kuča K. (2021b). Arbuscular mycorrhizal fungi alleviate drought stress in trifoliate orange by regulating $\mathrm{H}^{+}$-ATPase activity and gene expression. Frontiers in Plant Science 12:659694. https://doi.org/10.3389/fpls.2021.659694

Cheng LT, Liu ZY, Guo QS, Zhu GS (2009). Advances in studies on arbuscular mycorrhizas in medicinal plants. Chinese Traditional and Herbaldrugs 40:156-160. https://doi.org/10.3321/j.issn:0253-2670.2009.01.047

Cheng XF, Wu HH, Zou YN, Wu QS, Kuča K (2021). Mycorrhizal response strategies of trifoliate orange under wellwatered, salt stress, and waterlogging stress by regulating leaf aquaporin expression. Plant Physiology and Biochemistry 162:27-35. https://doi.org/10.1016/j.plaphy.2021.02.026 
Copetta A, Lingua G, Berta G (2006). Effects of three AM fungi on growth, distribution of glandular hairs, and essential oil production in Ocimum basilicum L. var. Genovese. Mycorrhiza 16(7):485-494. https://doi.org/10.1007/s00572-006-0065-6

Das A, Kamal S, Shakil N A, Sherameti I, Oelmüller R, Dua M, Narendra Tuteja N, Johri A K, Varma A (2012). The root endophyte fungus Piriformospora indica leads to early flowering, higher biomass and altered secondary metabolites of the medicinal plant, Coleus forskohlii. Plant Signaling and Behavior 7(1):103-112. https://doi.org/10.4161/psb.7.1.18472

Deshmukh S, Hueckelhoven R, Schaefer P, Imani J, Sharma M, Weiss M, Frank Waller, and Karl-Heinz Kogel (2006). The root endophytic fungus piriformospora indica requires host cell death for proliferation during mutualistic symbiosis with barley. Proceedings of the National Academy of Sciences of the United States of America 103(49):18450-18457. https://doi.org/10.1073/pnas.0605697103

Evelin H, Giri B, Kapoor R (2011). Contribution of Glomus intraradices inoculation to nutrient acquisition and mitigation of ionic imbalance in NaCl-stressed Trigonella foenumgraecu. Mycorrhiza 22 (3):203-217. https://doi.org/10.1007/s00572-011-0392-0

Fan JH, Zou YD, Han ZQ, Li YS (2017). Effects of AM fungi on the infection and growth of licorice. Hubei Agricultural Science 56 (4):670-673. https://doi.org/10.14088/j.cnki.issn0439-8114.2017.04.019

Fan JH, Yang GT, Qiang ML, Hai ZJ (2006). Effect of AMF on the content of berberine, jatrorrhizine and palmatine of Phellodendron amurense seedlings. Protection Forest Science and Technology 5:24-26. https://doi.org/10.3969/j.issn.1005-5215.2006.05.010

Gai JP, Liu RJ, Meng XX (2000). Arbuscular mycorrhizal fungi in the rhizosphere of wild plants. Mycosystema 19(2):2428. https://doi.org/10.3969/j.issn.1672-6472.2000.02.011

Gao AX, He XL (2007). Ecological study on am fungi around roots of medicinal plants in the middle area of Hebei province. Agricultural Research in the Arid Areas 25(3):196-202. https://doi.org/10.1016/S18722040(07)60079-6

He F, Sheng M, Tang M (2017). Effects of Rhizophagus irregularis on photosynthesis and antioxidative enzymatic system in Robinia pseudoacacia L. under drought stress. Frontiers in Plant Science 8:183. https://doi.org/10.3389/fpls.2017.00183

He JD, Zou YN, Wu QS, Kuča K (2020). Mycorrhizas enhance drought tolerance of trifoliate orange by enhancing activities and gene expression of antioxidant enzymes. Scientia Horticulturae 262:108745. https://doi.org/10.1016/j.scienta.2019.108745.

$\mathrm{He}$ X, Li J, He C (2009). Effects of AM fungi on the chemical components of Salvia miltiorrhiza. Chinese Agricultural Science Bulletin 25(14):182-185. https://doi.org/CNKI:SUN:ZNTB.0.2009-14-045

Huang JH, Tan JF, Jie HK, Zeng RS (2011). Effects of inoculating arbuscular mycorrhizal fungi on Artemisia annua growth and its officinal components. Chinese Journal of Applied Ecology 22:1443-1449. https://doi.org/10.3724/SP.J.1011.2011.00353

Hashem A, Kumar A, Al-Dbass AM, Alqarawi AA, Al-Arjani AF, Singh G, Farooq M, Fathi Abd-Allah E (2019). Arbuscular mycorrhizal fungi and biochar improves drought tolerance in chickpea. Saudi Journal of Biological Sciences 26(3):614-624. https://doi.org/10.1016/j.sjbs.2018.11.005

Jiang P, Wang MY, Lu JC (2012). Arbuscular mycorrhizal fungi associated with medicinal plants in Zhangzhou, Fujian. Mycosystema 31(5):676-689.

Jang P (2012b). The resources and species diversity research on AM fungi occurring in medicinal plants of south Fujian. MSc Dissertation, Huqiao University, Xiameng.

Jia HM, Fang Q, Zhang SH, Yan ZY, Liu M (2020). Effects of AM fungi on growth and rhizosphere soil enzyme activities of Salvia miltiorthiza. Acta Prataculturae Sinica 29(6):83-92. https://doi.org/10.11686/cyxb2019494

Koul KK, Agarwa S, Lone R (2012). Diversity of arbuscular mycorrhizal fungi associated with the medicinal plants from gwalior-chambal region of Madhya Pradesh-India. American-Eurasian Journal of Agricultural and Environmental Sciences 12(8):1004-1011. https://doi.org/10.5829/idosiaejaes.2012.12.08.1846

Kapoor R, Anand G, Gupta P, Mandal, S (2016). Insight into the mechanisms of enhanced production of valuable terpenoids by arbuscular mycorrhiza. Phytochemistry Reviews 16:677-692. https://doi.org/10.1007/s11101016-9486-9

Karasawa T, Hodge A, Fitter AH (2012). Growth respiration and nutrient acquisition by the arbuscular mycorrhizal fungus Glomus mosseae and its host plant Plantago lanceolata in cooled soil. Plant, Cell and Environment 35:819-828. https://doi.org/10.1111/j.1365-3040.2011.02455.x 
Khan A, Ding ZT, Ishaq M, Khan I, Ahmed AA, Khan AQ, Guo XS (2020). Applications of beneficial plant growth promoting rhizobacteria and mycorrhizae in rhizosphere and plant growth: A review. International Journal of Agricultural and Biological Engineering 13(5):199-208. https://doi.org/10.25165/j.ijabe.20201305.5762

Kilam D, Saifi M, Abdin M Z, Agnihotri A, Varma A (2015). Combined effects of Piriformospora indica and Azotobacter chroococcum enhance plant growth, antioxidant potential and steviol glycoside content in Stevia rebaudiana. Symbiosis 66:149-156. 10.1007/s13199-015-0347-x. https://doi.org/10.1007/s13199-015-0347-x

Kilam D, Saifi M, Abdin MZ, Agnihotri A, Varma A (2017). Endophytic root fungus piriformospora indica affects transcription of steviol biosynthesis genes and enhances production of steviol glycosides in stevia rebaudiana. Physiological and Molecular Plant Pathology 97:40-48. https://doi.org/10.1016/j.pmpp.2016.12.003

Kumar A, Choudhary AK, Suri VK (2016). Influence of AM fungi, inorganic phosphorus and irrigation regimes on plant water relations and soil physical properties in okra (Abelmoschus esculentus L) - pea (Pisum sativum L) cropping system in Himalayan acid alfisol. Journal of Plant Nutrition 39:666-682. https://doi.org/10.1080/01904167.2015.1087030

Khalvati MA, Hu Y, Mozafar A, Schmidhalter U (2005). Quantification of water uptake by arbuscular mycorrhizal hyphae and its significance for leaf growth, water relations, and gas exchange of barley subjected to drought stress. Plant Biology 7(6):706-712. https://doi.org/10.1055/s-2005-872893

Labidi S, Jeddi FB, Tisserant B, Yousfi M, Sanaa M, Dalpé Y, Lounes-Hadj Sahraoui A (2015). Field application of mycorrhizal bioinoculants affects the mineral uptake of a forage legume (Hedysarum coronarium L.) on a highly calcareous soil. Mycorrhiza 25:297-309. https://doi.org/10.1007/s00572-014-0609-0

Langeroodi ARS, Osipitan OA, Radicetti E, Mancinelli R (2020). To what extent arbuscular mycorrhiza can protect chicory (Cichorium intybus L) against drought stress. Scientia Horticulturae 263:109109. https://doi.org/10.1016/j.scienta.2019.109109

Li HL, Xu LF, Li ZW, Zhao SX, Guo DQ, Rui L, Zhou N (2021). Mycorrhizas affect polyphyllin accumulation of Paris polyphyllavar. yunnanensis through promoting PpSE expression. Phyton-International Journal of Experimental Botany 90(5):1535-1547. Https://doi.org/10.32604/phyton.2021.015697

Li PM, Han RG, Liu J, Yang CQ (2011). Diversity of vesicular and arbuscular (VA) mycorrhizal fungi in major medicinal plants from Chongqing. Hunan Agricultural Sciences 3(141-142):146. https://doi.org/10.3969/j.issn.1006$060 X .2011 .03 .042$

Liang XF, Tang MJ, Lu LX, Zhao XY, Dai CC (2018). Effects of three arbuscular mycorrhizal fungi (AMF) species on the growth, physiology, and major components of essential oil of Atractylodes lancea. Chinese Journal of Ecology 37:1871-1879. https://doi.org/10.13292/j.1000-4890.201806.010

Liu CY, Zhang F, Zhang DJ, Srivastava AK, Wu QS, Zou YN (2018). Mycorrhiza stimulates root-hair growth and IAA synthesis and transport in trifoliate orange under drought stress. Scientific Reports 8(1):1978. https://doi.org/10.1038/s41598-018-20456-4

Liu JC, Ma Y, Tao JP, Gao KM, Liang QH (2015). Effects of AM fungus on root growth of Lonicera japonica under alternate dry and wet conditions in Karst regions of southwestern China. Journal of Beijing Forestry University 37:110-116. https://doi.org/10.13332/j.1000-1522.20150057

Lou BG, Sun C, Cai DG (2007). Piriformospora indica with multiple functions and its application prospects. Acta Phytophylacica Sinica 34:653-656. https://doi.org/10.3321/j.issn:0577-7518..06.017

Lu YQ, Wang Dong-xue, Lu XL, Li LM, Li Y, He XL (2011). Effects of AM fungi on physiological character and nutritional component of Atractylodes macrocephala under different N levels. Acta Botanica BorealiOccidentalia Sinica 31:351-356. https://doi.org/10.1016/j.actao.2011.02.010

Ma YF, Yang XH, Li PM, Tong RJ (2005). Investigation of the diversity of arbuscular mycorrhizal structure of medicinal plants in Chongqing. Journal of Southwest Agricultural University 27(3):406-409. https://doi.org/10.3969/j.issn.1673-9868.2005.03.031

Mandal S, Upadhyay S, Singh VP, Kapoor R (2015a). Enhanced production of steviol glycosides in mycorrhizal plants: a concerted effect of arbuscular mycorrhizal symbiosis on transcription of biosynthetic genes. Plant Physiology and Biochemistry 89:100-106. https://doi.org/10.1016/j.plaphy.2015.02.010

Mandal S, Upadhyay S, Wajid S, Ram M, Jain DC, Singh VP, Abdin MZ, Kapoor R (2015b). Arbuscular mycorrhiza increases artemisinin accumulation in Artemisia annua by higher expression of key biosynthesis genes via enhanced jasmonic acid levels. Mycorrhiza 25:345-357. https://doi.org/10.1007/s00572-014-0614-3

Mathur S, Tomar RS, Jajoo A (2019). Arbuscular mycorrhizal fungi (AMF) protect photosynthetic apparatus of wheat under drought stress. Photosynthesis Research 139(1):227-238. https://doi.org/10.1007/s11120-018-0538-4 
Mahobiya D, Kulkarni P (2018). Biodiversity of arbuscular mycorrhizal (AM) fungi associated with cultivated medicinal plants. Advances in Plant Sciences 24(1):125-128.

Meng LL, He JD, Zou YN, Wu QS, Kuča K (2020). Mycorrhiza-released glomalin-related soil protein fractions contribute to soil total nitrogen in trifoliate orange. Plant, Soil and Environment 66:183-189. https://doi.org/10.17221/100/2020-PSE

Osborne OG, De-Kayne R, Bidartondo MI, Hutton I, Savolainen V (2017). Arbuscular mycorrhizal fungi promote coexistence and niche divergence of sympatric palm species on a remote oceanic island. New Phytologist 217(3):1254-1266. https://doi.org/10.1111/nph.14850

Pan Y, Xiao CH, Chen ML, Zhou T, Ai Q, Song J (2013). Effects of arbuscular mycorrhizal fungi on growth and chemical composition of Chrysanthemum morifolium. Guizhou Agricultural Sciences 41(1):109-111. https://doi.org/10.3969/j.issn.1001-3601.2013.01.033

Pongrac P, Vogel-Mikus K, Regvar M, Tolrà R, Poschenrieder C, Barceló J (2008). Glucosinolate profiles change during the life cycle and mycorrhizal colonization in a $\mathrm{Cd} / \mathrm{Zn}$ hyperaccumulator Thlaspi praecox (Brassicaceae). Journal of Chemical Ecology 34(8):1038-1044. https://doi.org/10.1007/s10886-008-9502-7

Prasad A, Kumar S, Khaliq A, Pandey A (2011). Heavy metals and arbuscular mycorrhizal (AM) fungi can alter the yield and chemical composition of volatile oil of sweet basil (Ocimum basilicum L.). Biology and Fertility of Soils 47(8):853-861. https://doi.org/10.1007/s00374-011-0590-0

Prasad A, Kumar S, Pandey A, Chand, S (2012). Microbial and chemical sources of phosphorus supply modulate the yield and chemical composition of essential oil of rose-scented geranium (Pelargonium species) in sodic soil. Biology and Fertility of Soils 48(1):117-122. https://doi.org/10.1007/s00374-011-0578-9

Parmita Z, Apurbo KR, Nurus SK, Nurul A, Tanzima Y (2008). Arbuscular mycorrhizal status of medicinal plants in Rajshahi University Campus. Mycosystema 27(4):543-553.

Radhika KP, Rodrigues BF (2010). Arbuscular mycorrhizal fungal diversity in some commonly occurring medicinal plants of western ghats goa region. Journal of Forestry Research 21(1):45-52. https://doi.org/10.1007/s11676-0100007-1

Ren JH, Liu RX, Li YL (2007). Study on arbuscular mycorrhizae of Panax notoginseng. Microbiology China 34(2):224227. https://doi.org/10.3969/j.issn.0253-2654.2007.02.007

Schäfer P, Pfiffi S, Voll LM, Zajic D, Chandler PM, Waller F, ... Kogel KH (2010). Manipulation of plant innate immunity and gibberellin as factor of compatibility in the mutualistic association of barley roots with Piriformospora indica. Plant Journal 59(3):461-474. https://doi.org/10.1111/j.1365-313X.2009.03887.x

Shahabivand S, Parvaneh A, Aliloo AA (2017). Root endophytic fungus Piriformospora indica affected growth, cadmium partitioning and chlorophyll fluorescence of sunflower under cadmium toxicity. Ecotoxicology and Environmental Safety 145:496-502. https://doi.org/10.1016/j.ecoenv.2017.07.064

Satheesa J, Narayanan AK, Sakunthala M (2012). Induction of root colonization by Piriformospora indica leads to enhanced asiaticoside production in Centella asiatica. Mycorrhiza 22:195-202. https://doi.org/10.1007/s00572-011-0394-y

Sharma G, Agrawal V (2013). Marked enhancement in the artemisinin content and biomass productivity in Artemisia annua L. shoots co-cultivated with Piriformospora indica. World Journal of Microbiology and Biotechnology 29(6):1133-1138. https://doi.org/10.1007/s11274-013-1263-y

Sharma P, Kharkwal AC, Abdin MZ, Varma A (2014). Piriformospora indica improves micropropagation, growth and phytochemical content of (Aloe vera L.) plants. Symbiosis 64(1):11-23. https://doi.org/10.1007/s13199-0140298-7

Smith SE, Facelli E, Pope S, Smith FA (2010). Plant performance in stressful environments: interpreting new and established knowledge of the roles of arbuscular mycorrhizas. Plant and Soil 326(1-2):3-20. https://doi.org/10.1007/s11104-009-9981-5

Su Y, Liu LB, Cai XZ, Zhu CM, Liang JW, Tang GD (2018). Diversity of arbuscular mycorrhizal fungi of Begonia fimbristipula. Forestry and Environmental Science 34:8-14.

Sun C, Johnson JM, Cai DG, Sherameti I, Oelmüller R, Lou, BG (2010). Piriformospora indica confers drought tolerance in Chinese cabbage leaves by stimulating antioxidant enzymes, the expression of drought-related genes and the plastid-localized CAS protein. Journal of Plant Physiology 167(12):1009-1017. https://doi.org/10.1016/j.jplph.2010.02.013 
Swetha S, Padmavathi T, Tallapragada (2017). Study of acid phosphatase in solubilization of inorganic phosphates by Piriformospora indica. Polish Journal of Microbiology 65(4):407-412. https://doi.org/10.5604/17331331.1227666

Tebuqin, Bao YY (2015). Colonization characteristics of AMF in common mongolian medicinal plants of horqin sandy land. Inner Mongolia Agricultural Science and Technology 43(6):25-28. https://doi.org/10.3969/j.issn.10070907.2015.06.008

Ullah R, Alqahtani AS, Noman OMA, Alqahtani AM, Ibenmoussa S, Bourhia M (2020). A review on ethno-medicinal plants used in traditional medicine in the Kingdom of Saudi Arabia. Saudi Journal of Biological Sciences 27(10):2706-2718. https://doi.org/10.1016/j.sjbs.2020.06.020

Vadassery J, Ritter C, Venus Y, Cameh I, Varma A, Shahollari B, Novák O, Strnad M, Ludwig-Müller J, Oelmüller R (2008). The role of auxins and cytokinins in the mutualistic interaction between Arabidopsis and Piriformospora indica. Molecular Plant-Microbe Interactions 21(10):1371-1383. https://doi.org/10.1094/MPMI-21-10-1371

Varma A, Verma S, Sudha, Sahay N, Bütehorn B, Franken P (1999). Piriformospora indica, a cultivable plant-growthpromoting root endophyte. Applied and Environmental Microbiology 65(6):2741-2744. https://doi.org/10.1128/AEM.65.6.2741-2744.1999

Vassilev N, Eichler-Löbermann B, Flor-Peregrin E, Martos V, Reyes A, Vassileva M (2017). Production of a potential liquid plant bio-stimulant by immobilized Piriformospora indica in repeated-batch fermentation process. AMB Express 7(1):106. https://doi.org/10.1186/s13568-017-0408-Z

Verma S, Varma A, Rexer KH, Hassel A, Kost G, Sarbhoy A, Bisen P, Britta B, Philipp F (1998). Piriformospora indica, gen. et sp. nov. a new root-colonizing fungus. Mycologia 90(5):896-903. https://doi.org/10.2307/3761331

Wei GT, Wang HG (1991). Effect of vesicular-arbuscular mycorrhizal fungi on growth, nutrient uptake and synthesis of volatile oil in Schizonepeta tenuifolia briq. China Journal of Chinese Materia Medica 16(3):139-142.

Wei GT, Wang HG (1989). Effects of VA mycorrhi zal fungi on growth, nutrient uptake and effective compounds in Chinese medicinal herb Daturastra monium L. Scientia Agricultura Sinica 22(5):56-61.

Wei M, Tong QY, Chai RJ, Ding JH (2018). Effect of orchid mycorrhizal fungi on growth, antioxidant defense and related gene expression of dendrobium of ficianle under drought stress. Acta Botanica Boreali-Occidentalia Sinica 38(10):1905-1912. https://doi.org/10.7606/j.issn.100-4025.2018.10.1905

Welling MT, Liu L, Rose TJ, Waters D, Benkendorff K (2016). Arbuscular mycorrhizal fungi: effects on plant terpenoid accumulation. Plant Biology 18:552-562. https://doi.org/10.1111/plb.12408

Wu QS, He JD, Srivastava AK, Zou YN, Kuča K (2019). Mycorrhiza enhances drought tolerance of citrus by altering root fatty acid compositions and their saturation levels. Tree Physiology 39(7):1149-1158. https://doi.org/10.1093/treephys/tpz039

Wu QS, Gao WQ, Srivastava AK, Zhang F, Zou YN (2020). Nutrient acquisition and fruit quality of Ponkan mandarin in response to AMF inoculation. Indian Journal of Agricultural Sciences 90:1563-1567.

Wu QS, Srivastava AK, Zou YN, (2013). AMF-induced tolerance to drought stress in citrus: a review. Scientia Horticulturae 164:77-87. https://doi.org/10.1016/j.scienta.2013.09.010

Wang XF, Zhang X, Zhao RH, Yu J, Gu W, Li R, Cao GH, He S (2020). Effect and mechanism of arbuscular mycorrhizal fungi in herbs. Chinese Journal of Experimental Traditional Medical Formulae 26(11):217-226. https://doi.org/10.13422/j.cnki.syfjx.20200811

Xie M, Deng Y, Lei XG, Fan L (2017). Effects of inoculating arbuscular mycorrhizal fungi on root growth of strawberry under drought stress. Journal of Anhui Agriculture Science 45(19):10-12.

Xie W, Hao ZP, Zhou XF, Jiang XL, Xu LJ, Wu SL, Zhao AH, Zhang X, Chen BD (2018). Arbuscular mycorrhiza facilitates the accumulation of glycyrrhizin and liquiritin in Glycyrrhiza uralensis under drought stress. Mycorrhiza 28(3):285-300. https://doi.org/10.1007/s00572-018-0827-y

Xie W, Hao ZP, Guo LP, Zhang X, Zhang SB, Wang YS, Chen BD (2020). Research advances in terpenoids synthesis and accumulation in plants as influenced by arbuscular mycorrhizal symbiosis. Biotechnology Bulletin, 36(9):4963. https://doi.org/10.13560/j.cnki.biotech.bull.1985.2020-0117

Xing XK, Li Y, Dalp Y (2000). Ten species of VAM fungi in five ginseng fields of Jilin province. Journal of Jilin Agricultural University 22(2):41-46.

Xu FL, Zhu ZY, He Y, Tian ZH (2021). Effects of Piriformospora indica on seed germination and protocorm growth of Dendrobium officinale. Journal of Tropical and Subtropical Botany 29(1):59-66. https://doi.org/10.11926/jtsb.4231 
Xu Y, Fan Y, Yu YH, Xu CY, Ge Y (2014). Effects of arbuscular mycorrhizal fungus on the growth and physiological salt tolerance parameters of Carthamus tinctorius seedlings under salt stress. Chinese Journal of Ecology 33:33953402. https://doi.org/10.13292/j.1000-4890.2014.0305

Xu L, Wang AA, Wang J, Wei Q, Zhang WY (2017). Piriformospora indica confers drought tolerance on Zea mays L. through enhancement of antioxidant activity and expression of drought-related genes. Crop Journal 5:251-258. https://doi.org/10.1016/j.cj.2016.10.002

Yadav K, Aggarwal A, Singh N (2013). Arbuscular mycorrhizal fungi (AMF) induced acclimatization, growth enhancement and colchicine content of micro propagated (Gloriosa superba L.) plantlets. Industrial Crops and Products 45:88-93. https://doi.org/10.1016/j.indcrop.2012.12.001

Yang J (2018). Research of antitumor effects and mechanisms of three medicinal plants. MSc Dissertation, South-Central University for Nationalities.

Yang L, Zou YN, Tian ZH, Wu QS, Kuča K (2021). Effects of beneficial endophytic fungal inoculants on plant growth and nutrient absorption of trifoliate orange seedlings. Scientia Horticulturae 277:109815. https://doi.org/10.1016/j.scienta.2020.109815

Yang L (2012). Effects of arbuscular mycorrhiza fungi on resistance to root disease by Salvia miltiorrhiza and related mechanisms. MSc Dissertation, Southwest Jiaotong University.

Zubek S, Błaszkowski J (2009). Medicinal plants as hosts of arbuscular mycorrhizal fungi and dark septate endophytes. Phytochemistry Reviews 8:571-580. https://doi.org/10.1007/s11101-009-9135-7

Zubek S, Stojakowska A, Anielska T, Turnau K (2010). Arbuscular mycorrhizal fungi alter thymol derivative contents of Inula ensifolia L. Mycorrhiza 20:497-504. https://doi.org/10.1007/s00572-010-0306-6

Zeng L, Wang M Y, Li F J, Zheng WJ (2014). Mechanism and effects of AM fungi on medicinal plants. Journal of Anhui Agricultural Sciences 42:4231-4233. https://doi.org/10.13989/j.cnki.0517-6611.2014.14.080

Zeng Y, Guo LP, Chen BD, Hao ZP, Wang JY, Huang LQ, ... Zhang Y (2013). Arbuscular mycorrhizal symbiosis and active ingredients of medicinal plants: current research status and prospective. Mycorrhiza 23:253-265. https://doi.org/10.1007/s00572-013-0484-0

Zarea MJ, Hajinia S, Karimi N, Goltapeh EM, Rejali F, Varma A (2012). Effect of Piriformospora indica and Azospirillum strains from saline or non-saline soil on mitigation of the effects of $\mathrm{NaCl}$. Soil Biology and Biochemistry 45:139146. https://doi.org/10.1016/j.soilbio.2011.11.006

Zhan HX, Du CH, Liu R, Shang CL, Zhang Y, Hu N, Pei XP (2020). Research progress of quality characters in medicinal plants. Modernization of Traditional Chinese Medicine and Materia Materia-World Science and Technology 22:2893-2898. https://doi.org/10.11842/wst.20190415006

Zhang F, Zou YN, WU QS (2019a). Effects of Funneliformis mosseae on the expression of antioxidant enzyme genes in trifoliate orange exposed to drought stress. Mycosystema 38:2043-2050. https://doi.org/10.13346/j.mycosystema.190199

Zhang F, Wang P, Zou YN, Wu QS, Kuča K (2019b). Effects of mycorrhizal fungi on root-hair growth and hormone levels of taproot and lateral roots in trifoliate orange under drought stress. Archives of Agronomy and Soil Science 65:1316-1330. https://doi.org/10.1080/03650340.2018.1563780

Zhang H, Sun JQ, Bao YY (2015). Advances in studies on plant secondary metabolites influenced by arbuscular mycorrhizal fungi. Journal of Agricultural Biotechnology 23(8):1093-1103. https://doi.org/10.3969/j.issn.1674-7968.2015.08.013

Zhang WH, Tang M (2006). On VA mycorrhiza fungi resources in the North of China. Journal of Northwest Forestry University 21(2):121-125. https://doi.org/10.3969/j.issn.1001-7461.2006.02.034

Zhang Y, Li J, Yao Q, Chen JZ, Hu YL, Liu XY, Huang YJ (2012). Effects of arbuscular mycorrhizal fungi on growth and nutrient uptake of Eriobotrya japonica plants under different water regimes. Acta Horticulturae Sinica 39:757762. https://doi.org/10.16420/j.issn.0513-353x.2012.04.020

Zhang ZF, Zhang JC, Huang YQ, Yang H, Luo, YJ, Luo, AY (2013). Effects of arbuscular mycorrhizal fungi on plant drought tolerance: research progress. Chinese Journal of Ecology 32(6):1607-1612. https://doi.org/10.13292/j.1000-4890.2013.0271

Zhao J (2010). Ecological distribution of arbuscular mycorrhizal fungi in the rhizosphere of ten species of medicinal plants in Anguo city, Hebei province. MSc Dissertation, Hebei University.

Zhao PJ, An F, Tang M (2007). Effects of arbuscular mycorrhiza fungi on drought resistance of Forsythia suspense. Acta Botanica Boreali-Occidentalia Sinica 27(2):396-399. https://doi.org/10.1016/S1872-2075(07)60055-7 
Zhao XH, Liu X, Chen SL, Xiang L (2019). Protection and application of genetic resources of medicinal plants. Modern Chinese Medicine 21:1456-1463. https://doi.org/10.13313/j.issn.1673-4890.20190903002

Zhao JL, He XL (2011). Effects of am fungi on drought resistance and content of chemical components in Angelica dahurica. Acta Agriculturae Boreali-Occidentalis Sinica 20(3):184-189. https://doi.org/10.7606/j.issn.10041389.2011.03.035

Zhou N, Xia CL, Jiang B, Bai ZC, Liu GM, Ma XK (2009). Arbuscular mycorrhizae in Paris polyphyllavar. Yunnanensis. China Journal of Chinese Materia Medica 34(14):1768-1772.

Zhu Y X, Song J, Xiao W J (2011). Identification of arbuscular mycorrhizal fungi from Salvia miltiorrhiza. Pharmacy and Clinics of Chinese Materia Medica 2(3):17-20.

Zou YN, Wu QS, Kuča K (2021a). Unravelling the role of arbuscular mycorrhizal fungi in mitigating the oxidative burst of plants under drought stress. Plant Biology 23(1):50-57. https://doi.org/10.1111/plb.13161

Zou YN, Zhang F, Srivastava AK, Wu QS, Kuča K (2021b). Arbuscular mycorrhizal fungi regulate polyamine homeostasis in roots of trifoliate orange for improved adaptation to soil moisture deficit stress. Frontiers in Plant Science 11:600792. https://doi.org/10.3389/fpls.2020.600792

OPEN ACCESS

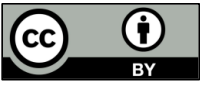

The journal offers free, immediate, and unrestricted access to peer-reviewed research and scholarly work. Users are allowed to read, download, copy, distribute, print, search, or link to the full texts of the articles, or use them for any other lawful purpose, without asking prior permission from the publisher or the author.

License - Articles published in Notulae Botanicae Horti Agrobotanici Cluj-Napoca are Open-Access, distributed under the terms and conditions of the Creative Commons Attribution (CC BY 4.0) License.

(c) Articles by the authors; UASVM, Cluj-Napoca, Romania. The journal allows the author(s) to hold the copyright/to retain publishing rights without restriction. 